University of Nebraska - Lincoln

DigitalCommons@University of Nebraska - Lincoln

\title{
Mitigating agrichemicals from an artificial runoff event using a managed riverine wetland
}

\author{
Richard E. Lizotte Jr. \\ USDA-ARS National Sedimentation Laboratory, Richard.lizotte@ars.usda.gov \\ F. Douglas Shields Jr \\ Mississippi State University \\ Justin N. Murdock \\ Mississippi State University \\ Robert Kröger \\ Mississippi State University \\ Scott S. Knight \\ Mississippi State University
}

Follow this and additional works at: https://digitalcommons.unl.edu/usdaarsfacpub

Part of the Agricultural Science Commons

Lizotte, Richard E. Jr.; Shields, F. Douglas Jr; Murdock, Justin N.; Kröger, Robert; and Knight, Scott S., "Mitigating agrichemicals from an artificial runoff event using a managed riverine wetland" (2012). Publications from USDA-ARS / UNL Faculty. 863.

https://digitalcommons.unl.edu/usdaarsfacpub/863

This Article is brought to you for free and open access by the U.S. Department of Agriculture: Agricultural Research Service, Lincoln, Nebraska at DigitalCommons@University of Nebraska - Lincoln. It has been accepted for inclusion in Publications from USDA-ARS / UNL Faculty by an authorized administrator of DigitalCommons@University of Nebraska - Lincoln. 


\title{
Mitigating agrichemicals from an artificial runoff event using a managed riverine wetland
}

\author{
Richard E. Lizotte Jr. *, F. Douglas Shields Jr., Justin N. Murdock, Robert Kröger, Scott S. Knight \\ USDA-ARS National Sedimentation Laboratory, Oxford, MS 38655, USA \\ Department of Wildlife Fisheries and Aquaculture, Mississippi State University, Box 9690, Mississippi State, MS, 39762, USA
}

\section{A R T I C L E I N F O}

\section{Article history:}

Received 15 September 2011

Received in revised form 6 April 2012

Accepted 9 April 2012

Available online 4 May 2012

\section{Keywords:}

Floodplain backwater

Hydrologic management

Sediment

Nutrients

Pesticides

\begin{abstract}
A B S T R A C T
We examined the mitigation efficiency of a managed riverine wetland amended with a mixture of suspended sediment, two nutrients (nitrogen and phosphorus), and three pesticides (atrazine, metolachlor, and permethrin) during a simulated agricultural runoff event. Hydrologic management of the $500 \mathrm{~m}-\mathrm{long}, 25 \mathrm{~m}-$ wide riverine wetland was done by adding weirs at both ends. The agrichemical mixture was amended to the wetland at the upstream weir simulating a four-hour, $\sim 1 \mathrm{~cm}$ rainfall event from a 16 ha agricultural field. Water samples ( $1 \mathrm{~L}$ ) were collected every 30 min within the first $4 \mathrm{~h}$, then every $4 \mathrm{~h}$ until $48 \mathrm{~h}$, and again on days $5,7,14,21$, and 28 post-amendment at distances of $0 \mathrm{~m}, 10 \mathrm{~m}, 40 \mathrm{~m}, 300 \mathrm{~m}$ and $500 \mathrm{~m}$ from the amendment point within the wetland for suspended solids, nutrient, and pesticide analyses. Peak sediment, nutrient, and pesticide concentrations occurred within $3 \mathrm{~h}$ of amendment at $0 \mathrm{~m}, 10 \mathrm{~m}, 40 \mathrm{~m}$, and $300 \mathrm{~m}$ downstream and showed rapid attenuation of agrichemicals from the water column with 79-98\%, 42-98\%, and 63-98\% decrease in concentrations of sediments, nutrients, and pesticides, respectively, within $48 \mathrm{~h}$. By day 28 , all amendments were near or below pre-amendment concentrations. Water samples at $500 \mathrm{~m}$ showed no changes in sediment or nutrient concentrations; pesticide concentrations peaked within $48 \mathrm{~h}$ but at $\leq 11 \%$ of upstream peak concentrations and had dissipated by day 28 . Managed riverine wetlands $\geq 1$ ha and with hydraulic residence times of days to weeks can efficiently trap agricultural runoff during moderate $(1 \mathrm{~cm})$ late-spring and early-summer rainfall events, mitigating impacts to receiving rivers.
\end{abstract}

Published by Elsevier B.V.

\section{Introduction}

Agricultural regions wherein major rivers with broad, lowgradient floodplains exist often contain numerous natural backwater aquatic habitats, such as wetlands, conducive to anthropogenic manipulation (Mitsch et al., 2005; Shields et al., 2005; Shields and Pearce 2010; Lizotte et al., 2009). Such freshwater wetlands, with minimal cost, can potentially be hydrologically managed to maximize their natural filtering capabilities to mitigate storm runoff from adjacent agricultural fields (Mitsch et al., 2005; Lizotte et al., 2009; Shields and Pearce, 2010). Costs to stakeholders such as farmers, land managers, land owners, and regulatory agencies would be less than the cost of full construction, implementation, and management of a constructed wetland of comparable size (Shields et al., 2005; Kadlec, 2006). Also, because natural backwater wetlands already provide preexisting hydrology, hydrophytes, and hydrosoils, these conditions would not need any "conditioning period" as for constructed wetlands (Mitsch and Gosselink, 2007). Despite these advantages, little information exists regarding the ability of anthropogenically

\footnotetext{
* Corresponding author at: USDA-ARS National Sedimentation Laboratory, P.O. Box 1157, Oxford, Mississippi 38655, USA. Tel.: + 1662281 5703; fax: +1 6622322988. E-mail address: Richard.lizotte@ars.usda.gov (R.E. Lizotte).
}

manipulated natural backwater wetlands in mitigating contaminants from agricultural runoff under controlled conditions.

Riverine backwater wetlands within river floodplains have important economic and ecological functions such as acting as filters and processors of a variety of agricultural contaminants including suspended sediment, nutrients and pesticides entering from adjacent agricultural fields (Reddy and DeLaune, 2008). The hydrology of such wetlands can be controlled to increase the efficacy of their natural filtering capabilities (Mitsch et al., 2002; Lizotte et al., 2009). Nutrient mitigation from agricultural sources has been a primary focus for several decades due to the increase in eutrophication of receiving lakes, rivers, streams and estuaries worldwide (Wetzel, 1992; Scanlon et al., 2007) and wetlands have long been known to be highly efficient at removing nutrients under favorable conditions (Mitsch and Gosselink, 2007). For these reasons, there is an increasing need to expand our knowledge of nutrient mitigation capabilities to efficiently maximize available wetland resources via hydraulic modification of riverine floodplain wetlands, when applicable. The purpose of this study was to assess the trapping efficiency of a modified riverine backwater wetland amended with a mixture of suspended sediment, two nutrients [nitrogen $(\mathrm{N})$ and phosphorus $(\mathrm{P})$ ], and three pesticides (atrazine, metolachlor, and permethrin) during a simulated agricultural runoff event. Previous study by Lizotte et al. (2009) within the same wetland 
system assessed the trapping of pesticides only. The study was limited in scope both spatially (only two sites: inflow and furthest downstream weir) and pollutant mixture complexity. The current study expands the previous work of Lizotte et al. (2009) by incorporating a broader spatial assessment, and more complex, and realistic, pollutant mixture, to better address questions of agricultural pollutant trapping and attenuation efficiency of the managed riverine wetland study site.

\section{Area description}

A reach of the Coldwater River $\sim 20 \mathrm{~km}$ downstream from Arkabutla Lake Dam in Tunica County, Mississippi, was selected because of the presence of $>20$ severed riverine backwater meander bends and other floodplain water bodies (Fig. 1). A severed riverine compound meander bend backwater $(\sim 2.5 \mathrm{~km}$ long $\times 40 \mathrm{~m}$ wide $)$ was selected for this study. The study site, inside the mainstem flood control levee, is the result of a $0.4 \mathrm{~km}$ cutoff constructed in 1941-42. Land-use both inside and outside the bend are in row-crop cultivation. However, a buffer of natural riparian vegetation 5-100 m wide occurs on both banks. The study site receives runoff from $\sim 350$ ha of cultivated land, primarily through an intermittent slough connected to a series of drainage ditches (Shields and Pearce, 2010). In fall of 2006, the study site was modified with the construction of two water control weirs ( $34^{\circ} 40^{\prime} 04.93^{\prime \prime} \mathrm{N}, 90^{\circ} 13^{\prime} 38.09^{\prime \prime}$ $\mathrm{W}$, and $34^{\circ} 40^{\prime} 15.15^{\prime \prime} \mathrm{N}, 90^{\circ} 13^{\prime} 35.36^{\prime \prime} \mathrm{W}$ ), creating a larger, deeper cell managed as a lake-type aquatic habitat and a smaller, shallower cell, $500 \mathrm{~m}$ long, $20 \mathrm{~m}$ wide, that supports wetland and terrestrial plants managed as a riverine wetland (Fig. 1). A mean water depth of $28 \mathrm{~cm}$ was measured in the wetland cell during the study period. The weir controlling the lake cell was located such that most runoff from adjacent fields was diverted into the wetland cell. Both weirs were designed with adjustable crest drainage structures (Mitsch and Gosselink, 2007) protected by "Clemson" beaver exclusion screens at their upstream intakes. Weirs were protected with riprap to allow for overflow in either direction. Flora within the managed backwater wetland was diverse. Mature forest dominated by oak (Quercus spp.) and, to a lesser extent, sycamore (Platanus occidentalis L.) bald cypress (Taxodium distichum (L.) Rich), and pawpaw (Asimina triloba (L.) Dunal), lined the banks of the backwater wetland. A diversity of tall herbaceous annuals, shrubs, grasses and herbs as well as woody species occurred within the main channel of the backwater wetland. Within the first $40 \mathrm{~m}$ downstream from the lake weir, Ludwigia peploides (HBK) and Commelina communis L. were observed. At $100 \mathrm{~m}$ downstream, Leersia oryzoides (L.) Sw. and Agrostis sp. dominated nearly $100 \%$ of the channel. Channel flora at $300 \mathrm{~m}$ was comprised of Rumex crispus L., Amaranthus sp., Leersia sp., and C. communis L. along the edge of the banks. Wetland vegetation at $500 \mathrm{~m}$ was comprised of Ludwigia sp., Mimulus ringens L., Leersia spp., Cyperus sp., Carex sp., Amaranthus sp., Xanthium strumarium L., Polygonum sp. and Taxodium distichum (L.) Rich.

\section{Methods}

On June $24,2009,611 \mathrm{~m}^{3}$ of water was released from the upstream lake cell portion of the study site into the modified wetland cell portion over about $4 \mathrm{~h}$ (Fig. 2), simulating agricultural runoff during an $\sim 1-\mathrm{cm}$ rainfall event from a 16-ha cultivated field. Simulated agricultural runoff comprised of local source suspended sediment (adjacent field soil), nutrients as $\mathrm{P}\left(42 \% \mathrm{P}_{2} \mathrm{O}_{5}\right)$ and $\mathrm{N}\left(34 \% \mathrm{NH}_{4} \mathrm{NO}_{3}\right)$, and pesticides as atrazine, $S$-metolachlor and permethrin was amended once simulating a "first flush" event. Current study target sediment, nutrient and pesticide concentrations are based upon previously reported results of concentrations of these constituents naturally occurring in runoff from agricultural fields within west Mississippi (Willis and McDowell, 1982; McDowell et al., 1989; Shields and Pearce, 2010). A total of $200 \mathrm{~g} \mathrm{NaCl}$

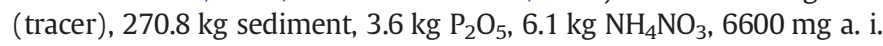
atrazine $+5220 \mathrm{mg}$ a. i. S-metolachlor (Bicep II Magnum ${ }^{\circledR}$ ), and $630.4 \mathrm{mg}$ a. i. permethrin (Hi Yield $38 \AA$ ) were injected into the backwater wetland at the upstream weir for the first $1.3 \mathrm{~h}$. A hydrograph for the artificial event was designed by scaling an observed hydrograph from the tributary slough so that the peak flow was equal to the maximum discharge that could be obtained by releasing water from the lake cell through the drainage structure into the wetland $\left(\sim 90 \mathrm{~m}^{3} \mathrm{~s}^{-1}\right)$. During the event, the hydrograph was generated by

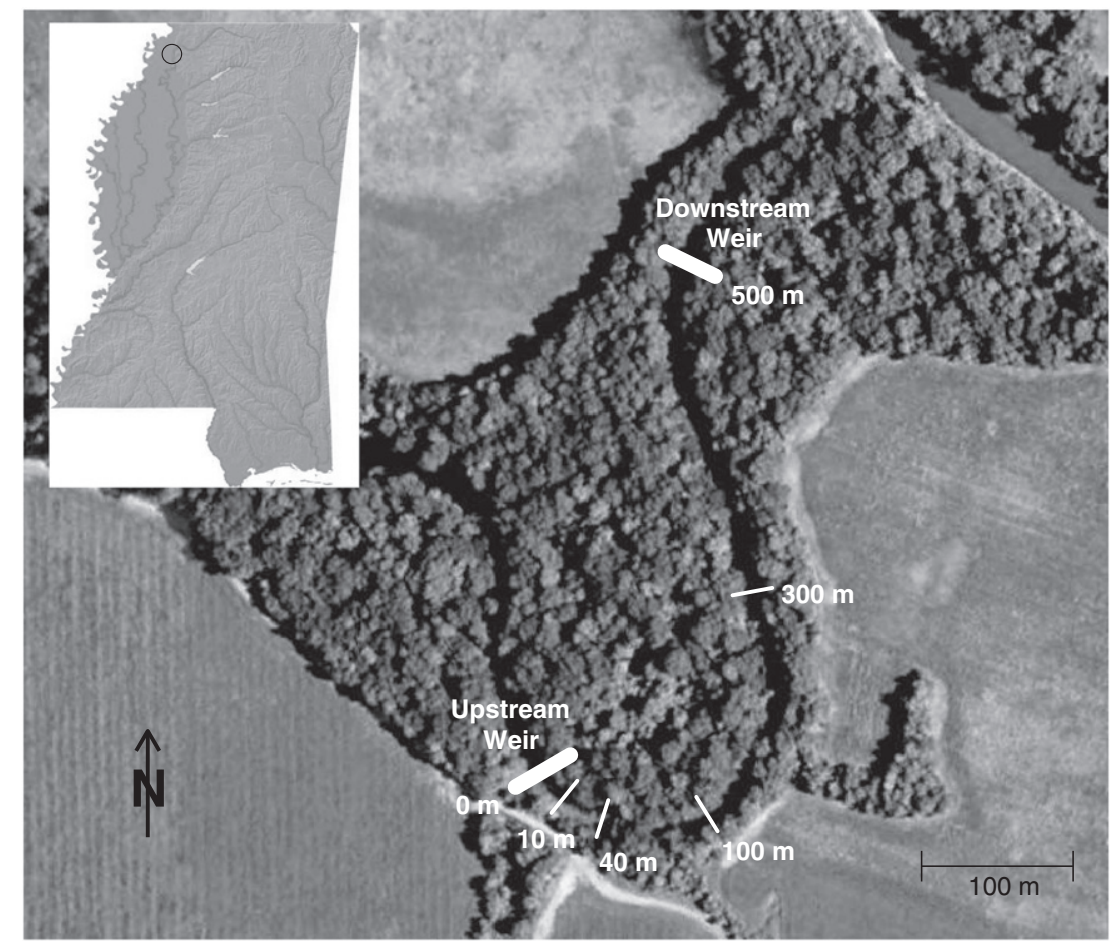

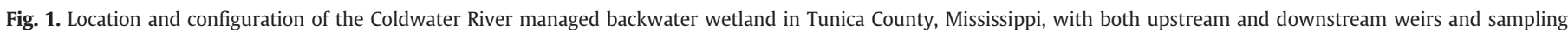
locations. 


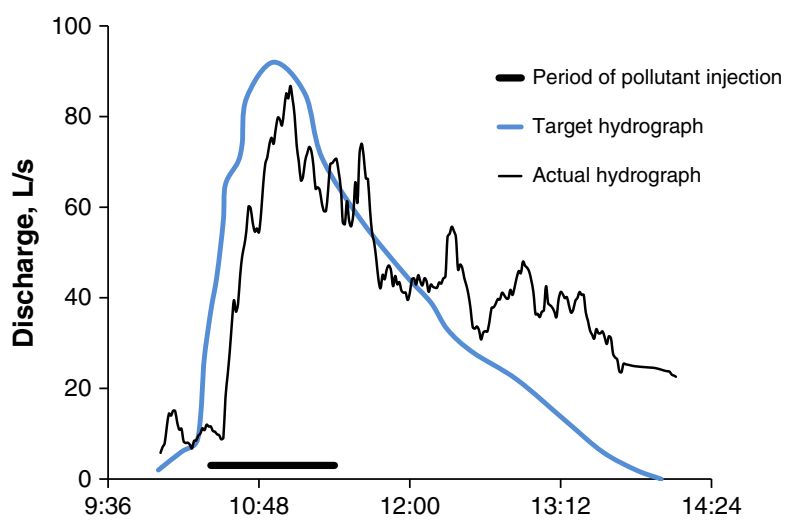

Fig. 2. Measured discharge $\left(\mathrm{L} \mathrm{s}^{-1}\right)$ during the simulated rainfall event. Water was released from the lake cell into the wetland cell of the managed backwater wetland.

removing and replacing flashboards from the drainage structure at set times. Flow rates were continuously recorded by measuring the depth of flow over the weir and converting flow depth to discharge using a rating curve provided by the manufacturer (Agri Drain Corporation, Adair, Iowa, USA). Flow rates were verified using acoustic (ISCO 2150 Area Velocity Flow Module, Teledyne ISCO, Lincoln, NE, USA) and electromagnetic devices (Marsh McBirney Model 2000 Flow Meter, Marsh-McBirney, Inc., Frederick, MD, USA) in the discharge channel. Outflow from the wetland was monitored throughout the experiment using а НОВО U20 ${ }^{\mathrm{TM}}$ logging pressure transducer (Onset Computer Corporation, Bourne, MA, USA) to record the depth of flow over the weir structure.

Target suspended sediment concentration ( $\left.\mathrm{SS}_{\text {target }}\right)$ for the artificial runoff event was set equal to the maximum observed June SS concentration for the slough tributary to the wetland $(325 \mathrm{mg} / \mathrm{L})$. The slough conveys runoff from a series of drainage ditches draining 350 ha of cultivated land into the wetland. Grab samples were collected from this slough (when it contained water) during 2007-2009. Field soil was obtained from the adjacent floodplain, weighed, and amended to the flow through the drainage structure during the entire 4-h duration of the artificial event. Turbulence of flow through the structure was adequate to fully suspend the amended sediment. The mass of soil to be added during each increment of the event was determined as follows. First the volume of water to be released during each time increment $\left(\mathrm{V}_{\mathrm{wi}}, \mathrm{L}\right)$ was computed by multiplying the target flow rate $\left(\mathrm{Q}_{\mathrm{wi}}, \mathrm{L} \mathrm{s}^{-1}\right)$ times the length of the time increment $\left(\Delta t_{i}, s\right)$ :

$V_{w i}=Q_{w i} * \Delta t_{i}$

Then the mass of soil to be added during each increment $\left(\mathrm{W}_{\mathrm{si}}, \mathrm{mg}\right)$ was determined by

$W_{s i}=\frac{\left[S S_{\text {target }}-S S_{\text {lake }}\right] V_{w i}}{1-w}$

where $S S_{\text {lake }}=S S$ of lake cell waters used to generate artificial runoff and $w=$ water content of soil, assumed to be $=30 \%$ based on Mostovoy and Anantharaj (2008).

Water samples $(1 \mathrm{~L})$ were collected every 30 min within the first $4 \mathrm{~h}$; every $4 \mathrm{~h}$ until $48 \mathrm{~h}$; and on days $5,7,14,21$, and 28 postamendment at distances of $10 \mathrm{~m}, 40 \mathrm{~m}, 300 \mathrm{~m}$ and $500 \mathrm{~m}$ from the injection point within the wetland. Samples collected during the first $48 \mathrm{~h}$ were obtained using an automated pumping sampler (ISCO Model 3700, Teledyne ISCO, Lincoln, NE, USA) modified from Smith (1993). Sample collection at $100 \mathrm{~m}$ was modified due to infrequent inundation at this site caused by a $0.4-0.6 \mathrm{~m}$ increase in elevation resulting from sediment aggradation near the mouth of a large gully entering the wetland from the south (Fig. 1). As a result, samples were obtained when water was present which only occurred during the artificial runoff event (1-5 h; 8 samples) and again on day 28 (1 sample). Sample containers were one (1) liter polyethylene plastic bottles fitted with a Teflon-lined screw cap. Samples were placed on ice, transported to the USDA-ARS National Sedimentation Laboratory, and stored at $4{ }^{\circ} \mathrm{C}$ (typically $<24 \mathrm{~h}$ ) for target constituent analysis. Samples collected after $24 \mathrm{~h}$ were in one liter glass jars fitted with a Teflon lined screw cap and treated as described previously.

Analyses for suspended solids, $\mathrm{N}$ and $\mathrm{P}$ were conducted according to APHA (2005). In brief, suspended sediments and nutrients were analyzed as follows: total suspended solids (TSS), dried at $180^{\circ} \mathrm{C}$; total $\mathrm{PO}_{4}^{-}-\mathrm{P}$, persulfate digestion with ascorbic acid colorimetric method; soluble $\mathrm{PO}_{4}^{-}-\mathrm{P}$, filtered through a $45 \mu \mathrm{m}$ cellulose nitrate filter and analyzed using the ascorbic acid colorimetric method; $\mathrm{NH}_{4}^{+}-\mathrm{N}$, phenate method; $\mathrm{NO}_{3}^{-}-\mathrm{N}$, cadmium reduction colorimetric method; $\mathrm{NO}_{2}^{-}-\mathrm{N}$, colorimetric method; and total $\mathrm{N},\left(\mathrm{NO}_{3}^{-}-\mathrm{N}+\mathrm{NO}_{2}^{-}-\right.$ $\mathrm{N}+$ total Kjeldahl $\mathrm{N}$ ) block digestion and flow injection analysis method. Colorimetric analyses were performed using a ThermoSpectronic Genesys ${ }^{\mathrm{TM}} 10$ ultraviolet (UV) spectrophotometer (Spectronic Instruments, Inc., Rochester, NY, USA). Method detection limits were: $10 \mathrm{mg} \mathrm{L}^{-1}$, TSS; $0.01 \mathrm{mg} \mathrm{L}^{-1}$, total $\mathrm{PO}_{4}^{-}-\mathrm{P}$, soluble $\mathrm{PO}_{4}^{-}-\mathrm{P}, \mathrm{NO}_{3}^{-}-\mathrm{N}$, and $\mathrm{NO}_{2}^{-}-\mathrm{N}$; and $0.02 \mathrm{mg} \mathrm{L}^{-1}, \mathrm{NH}_{4}^{+}-\mathrm{N}$ and $\mathrm{TN}$.

Pesticide analyses were conducted according to Smith et al. (2007). In brief, pesticides were extracted using pesticide-grade ethyl acetate, dried over anhydrous $\mathrm{Na}_{2} \mathrm{SO}_{4}$ and concentrated to near dryness by rotary evaporation. The extract was then subjected to silica gel column chromatography cleanup, and concentration to $1 \mathrm{~mL}$ volume under high purity dry nitrogen for GC analysis. Pesticide recoveries and extraction efficiencies, based on fortified samples, were $\geq 90 \%$ for targeted pesticides (Smith et al., 2007). Two Agilent HP model 6890 gas chromatographs (Agilent Technologies, Inc., Waldbronn, Germany) equipped with dual Agilent HP 7683 ALS autoinjectors, dual split-splitless inlets, dual capillary columns, an Agilent HP Kayak XA Chemstation, and the autoinjector set at $1.0 \mu \mathrm{L}$ injection volume fast mode were used for all targeted pesticide analyses according to Smith et al. (2007). The first of the two Agilent HP 6890 GCs was equipped with two micro electron capture detectors ( $\mu \mathrm{ECDs}$ ) and the second 6890 with one $\mu \mathrm{ECD}$, one $\mathrm{N}-\mathrm{P}$ detector (NPD), and an Agilent HP 5973 mass selective detector (MSD). The primary analytical column was an Agilent HP 5MS capillary column, $30 \mathrm{~m} \times 0.25 \mathrm{~mm}$ i. d. $\times 0.25 \mu \mathrm{m}$ film thickness. Column oven temperatures were: initial at $85^{\circ} \mathrm{C}$ for $1 \mathrm{~min}$; ramp at $25{ }^{\circ} \mathrm{C}$ to $190{ }^{\circ} \mathrm{C}$; hold at $190{ }^{\circ} \mathrm{C}$ for $25 \mathrm{~min}$; ramp at $25^{\circ} \mathrm{C}$ to $230{ }^{\circ} \mathrm{C}$ and hold for $30 \mathrm{~min}$. The carrier gas used was ultra-high purity (UHP) helium at $28 \mathrm{~cm} / \mathrm{s}$ and inlet temperature at $250{ }^{\circ} \mathrm{C}$. The $\mu \mathrm{ECD}$ temperature was $325^{\circ} \mathrm{C}$ with a constant make up gas flow of $40 \mathrm{~mL} / \mathrm{min}$ UHP nitrogen. Method detection limits were: $0.1 \mu \mathrm{g} \mathrm{L}^{-1}$, $S$-metolachlor, cis-permethrin, and trans-permethrin; $0.01 \mu \mathrm{g} \mathrm{L}^{-1}$, atrazine.

In addition, water quality parameters of temperature, $\mathrm{pH}$, and dissolved oxygen were measured in-situ in the managed riverine wetland from June 16, 2009 through July 22, 2009 at $10 \mathrm{~m}, 40 \mathrm{~m}$, $300 \mathrm{~m}$, and $500 \mathrm{~m}$ using four Yellow Springs Instruments (YSI) 6290 multi-parameter water quality monitoring systems (Yellow Springs, $\mathrm{OH}, \mathrm{USA}$ ). Measurements were collected hourly during pretreatment days -7 to -3 (week -1 ), treatment days $0-5$ (week 1 ), 7-11 (week 2), 14-19 (week 3), and 21-28 (week 4). On two occasions, insitu measurements were not recorded due to equipment failure and are reported as "no data".

Weekly means and standard deviations $( \pm S D)$ were determined for all four in-situ parameters. Forward stepwise linear regressions were conducted according to Berenson et al. (1983) to assess multiple independent variables that could influence observed changes in concentrations of amended agrichemicals. Independent variables of distance from inflow (distance), sampling time (time), and wetland water volume at sampling time (volume) were used to predict each 


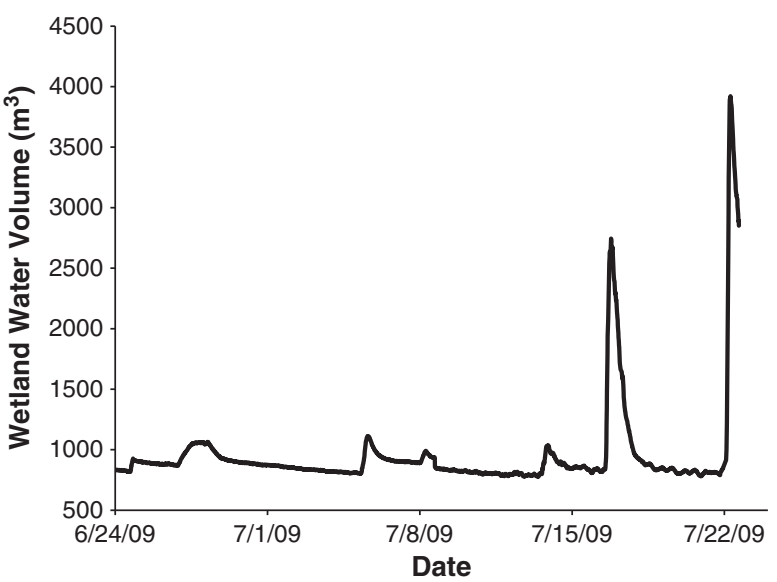

Fig. 3. Continuous ( $15 \mathrm{~min}$ intervals) wetland water volume $\left(\mathrm{m}^{3}\right)$ during the managed backwater wetland study period June 24-July 22, 2009.

dependent variable of measured parameters of amended agrichemicals (TSS, nutrients, and pesticides). Independent variables were added or removed using F-to-enter of 4.0 and F-to-remove of 3.9. Standardized dimensionless regression coefficients and coefficients of determination were calculated and reported for each variable. When possible, regression coefficients of determination calculated from single exponential decay formulas for amended agrichemical concentrations at each site were generated by running non-linear regressions. The resulting formulas were used to determine aqueous dissipation half-lives $\left(T_{1 / 2}\right)$ within the wetland. All statistical analyses were conducted using SigmaStat ${ }^{\circledR}$ v.2.03 (Chicago, IL, USA) statistical software (SPSS, 1997). Statistical significance level for all models was set at $5 \%(p \leq 0.05)$ for all analyses (Glantz, 1997).

The wetland was not a flow through system and all water released from the lake cell during the artificial runoff event stayed within the wetland. However, the release produced a defined pulse as water

Table 1

Mean $( \pm S D)$ weekly in-situ water quality characteristics for the managed backwater wetland during the study period June 17-July 22, 2009.

\begin{tabular}{|c|c|c|c|c|}
\hline Distance & $\begin{array}{l}\text { Temperature } \\
\left({ }^{\circ} \mathrm{C}\right)\end{array}$ & $\begin{array}{l}\text { Conductivity } \\
\left(\mu \mathrm{Sm}^{-1}\right)\end{array}$ & $\begin{array}{l}\text { Dissolved oxygen } \\
\left(\mathrm{mg} \mathrm{L}^{-1}\right)\end{array}$ & $\mathrm{pH}$ \\
\hline \multicolumn{5}{|l|}{$10 \mathrm{~m}$} \\
\hline Week - 1 & $30.3 \pm 3.3$ & $151.3 \pm 15.6$ & $3.3 \pm 2.2$ & $7.1 \pm 0.2$ \\
\hline Week 1 & $30.4 \pm 3.2$ & $179.3 \pm 20.5$ & $3.8 \pm 3.5$ & $6.8 \pm 0.2$ \\
\hline Week 2 & No data & No data & No data & No data \\
\hline Week 3 & $28.6 \pm 3.3$ & $149.6 \pm 39.8$ & $4.8 \pm 4.7$ & $7.0 \pm 0.5$ \\
\hline Week 4 & $25.2 \pm 2.3$ & $111.8 \pm 28.7$ & $4.3 \pm 2.6$ & $6.7 \pm 0.2$ \\
\hline \multicolumn{5}{|l|}{$40 \mathrm{~m}$} \\
\hline Week - 1 & $30.9 \pm 3.6$ & $173.8 \pm 19.7$ & $4.0 \pm 4.2$ & $7.1 \pm 0.3$ \\
\hline Week 1 & $31.2 \pm 3.6$ & $178.4 \pm 19.4$ & $3.8 \pm 3.8$ & $6.9 \pm 0.3$ \\
\hline Week 2 & $26.9 \pm 4.2$ & $101.6 \pm 19.9$ & $4.7 \pm 3.8$ & $6.6 \pm 0.6$ \\
\hline Week 3 & $29.1 \pm 3.5$ & $188.6 \pm 46.5$ & $5.2 \pm 4.8$ & $7.1 \pm 0.5$ \\
\hline Week 4 & $25.5 \pm 2.2$ & $111.1 \pm 31.1$ & $4.2 \pm 2.9$ & $6.8 \pm 0.2$ \\
\hline \multicolumn{5}{|l|}{$300 \mathrm{~m}$} \\
\hline Week - 1 & $27.3 \pm 2.1$ & $166.5 \pm 9.4$ & $2.3 \pm 1.5$ & $7.0 \pm 0.1$ \\
\hline Week 1 & $28.1 \pm 2.0$ & $156.9 \pm 13.2$ & $2.6 \pm 1.4$ & $6.9 \pm 0.1$ \\
\hline Week 2 & $25.2 \pm 1.9$ & $149.8 \pm 30.7$ & $2.8 \pm 1.8$ & $6.8 \pm 0.3$ \\
\hline Week 3 & $26.2 \pm 1.6$ & $146.9 \pm 21.9$ & $2.5 \pm 1.4$ & $6.7 \pm 0.2$ \\
\hline Week 4 & $23.5 \pm 1.9$ & $102.0 \pm 26.7$ & $3.0 \pm 1.6$ & $6.5 \pm 0.2$ \\
\hline \multicolumn{5}{|l|}{$500 \mathrm{~m}$} \\
\hline Week - 1 & No data & No data & No data & No data \\
\hline Week 1 & $27.8 \pm 1.9$ & $153.0 \pm 4.0$ & $6.0 \pm 2.8$ & $7.1 \pm 0.3$ \\
\hline Week 2 & $26.5 \pm 1.7$ & $147.2 \pm 24.2$ & $4.0 \pm 2.7$ & $7.1 \pm 0.4$ \\
\hline Week 3 & $27.2 \pm 1.5$ & $126.4 \pm 12.6$ & $4.1 \pm 3.2$ & $7.0 \pm 0.3$ \\
\hline Week 4 & $24.3 \pm 1.6$ & $82.8 \pm 18.5$ & $3.7 \pm 1.7$ & $6.6 \pm 0.2$ \\
\hline
\end{tabular}

traveled from the release point to the downstream weir, taking approximately $5 \mathrm{~h}$ to pass the $500 \mathrm{~m}$ station. Nutrient and pesticide uptake lengths $\left(\mathrm{S}_{\mathrm{w}}\right.$, the average distance a molecule travels before it is removed from the water column) of the initial pulse were estimated by following changes in $\mathrm{NH}_{4}^{+}-\mathrm{N}$, soluble $\mathrm{PO}_{4}^{-}-\mathrm{P}$, atrazine, $S$-metolachlor, and permethrin relative to a conservative tracer (chloride, $\mathrm{Cl}^{-}$) in the pulse (Tank et al., 2008). We calculated the mass of each nutrient or pesticide relative to the mass of $\mathrm{Cl}^{-}$as the pulse crossed each station. The mass of each pollutant was estimated by integrating the area under the curve, background corrected concentration vs. time plot using the trapezoidal method. Uptake lengths were calculated by dividing background corrected mass of pollutant by background corrected $\mathrm{Cl}^{-}$mass at each station. The natural logarithm of the ratios at each station was plotted against distance, and the absolute value of the inverse of the slope is $\mathrm{S}_{\mathrm{w}}$ (Stream Solute Workshop, 1990).

\section{Results}

The simulated hydrograph was quite similar to the targeted model, with peak discharge of $85 \mathrm{~L} \mathrm{~s}^{-1}$ about $1 \mathrm{~h}$ after flow initiation (Fig. 2). No outflow from the wetland occurred during simulated event, and although a total of approximately $149 \mathrm{~mm}$ of rainfall was
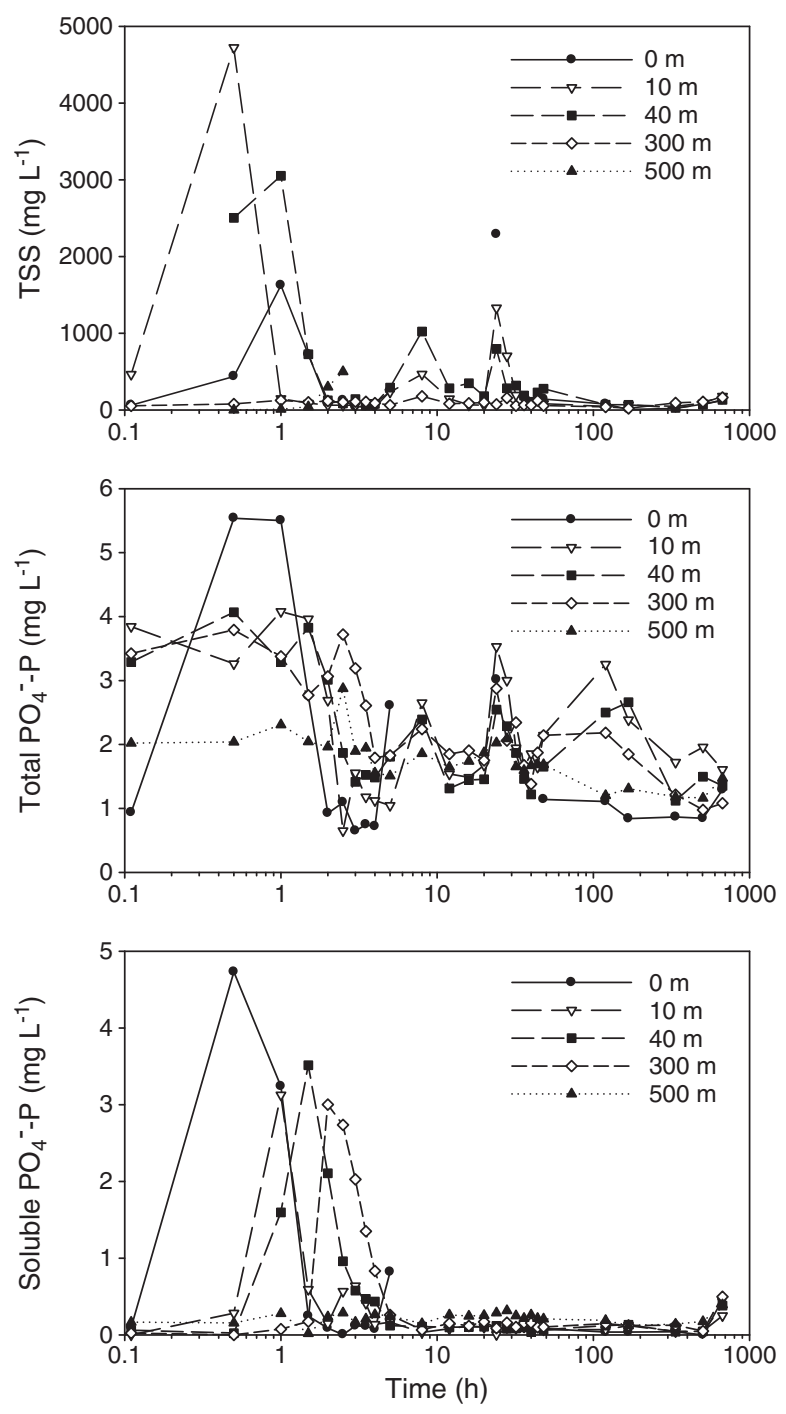

Fig. 4. Total suspended solids (TSS), total $\mathrm{PO}_{4}^{-}-\mathrm{P}$ and soluble $\mathrm{PO}_{4}^{-}-\mathrm{P}$ concentrations $\left(\mathrm{mg} \mathrm{L}^{-1}\right)$ in the managed backwater wetland before, during, and after an artificial runoff event. 

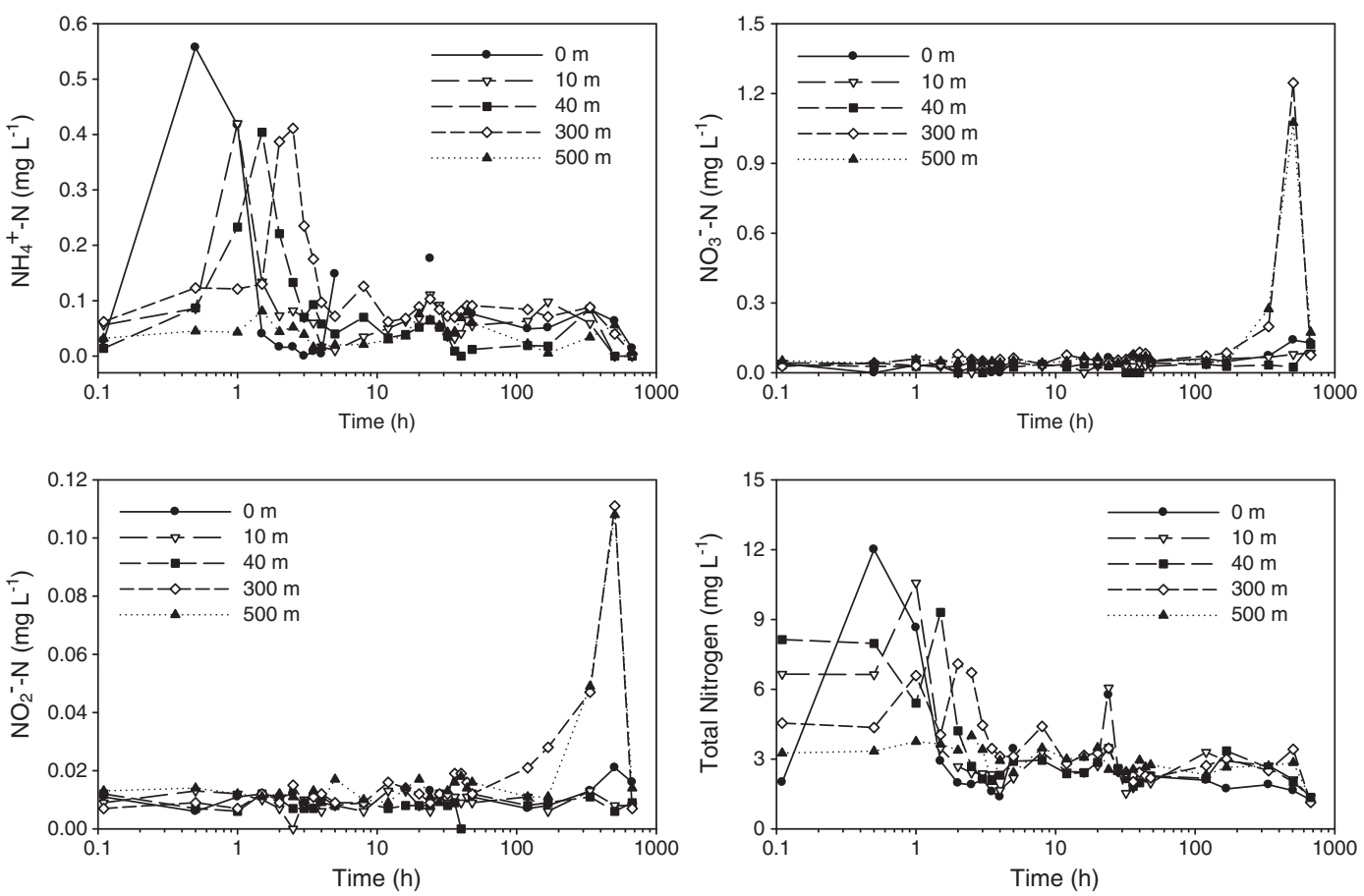

Fig. 5. Nitrogen $\left(\mathrm{NH}_{4}^{+}-\mathrm{N}, \mathrm{NO}_{3}^{-}-\mathrm{N}, \mathrm{NO}_{2}^{-}-\mathrm{N}\right.$, and total nitrogen) concentrations ( $\left.\mathrm{mg} \mathrm{L}^{-1}\right)$ in the managed backwater wetland before, during, and after an artificial runoff event.

recorded by the nearest rain gage during the monitoring period (reported at Sarah, Mississippi), no outflow occurred during the period following the event until day 22 (Fig. 3). Local thunderstorms triggered outflows from the wetland to the river on days 22 and 27-28. Over the entire 28-d study period, the average wetland water volume was $967 \mathrm{~m}^{3}$, while the total inflows to the wetland from the simulated event and natural runoff were $611 \mathrm{~m}^{3}$ and $5600 \mathrm{~m}^{3}$, respectively (Fig. 3). In-situ water quality of the managed wetland was typical of freshwater riverine wetland habitats in the southeastern US (Table 1). Water temperature was indicative of climatic conditions in Mississippi during summer, with means ranging from 23 to $40{ }^{\circ} \mathrm{C}$. Range of conductivity means was from 102 to $189 \mu \mathrm{S} \mathrm{cm}^{-1}$, mean $\mathrm{pH}$ was circumneutral ranging from 6.5 to 7.1, and mean dissolved oxygen ranged from 2.3 to $5.2 \mathrm{mg} \mathrm{L}^{-1}$, indicative of shallow $(<1 \mathrm{~m})$ water depths. Prior to amendment, pretreatment concentrations of simulated agricultural runoff constituents were measured at each site. TSS was $<100 \mathrm{mg} \mathrm{L}^{-1}$ at each site; total $\mathrm{PO}_{4}^{-}-\mathrm{P}$ ranged from 1 to $3.4 \mathrm{mg} \mathrm{L}^{-1}$ (Fig. 4); soluble $\mathrm{PO}_{4}^{-}-\mathrm{P}$
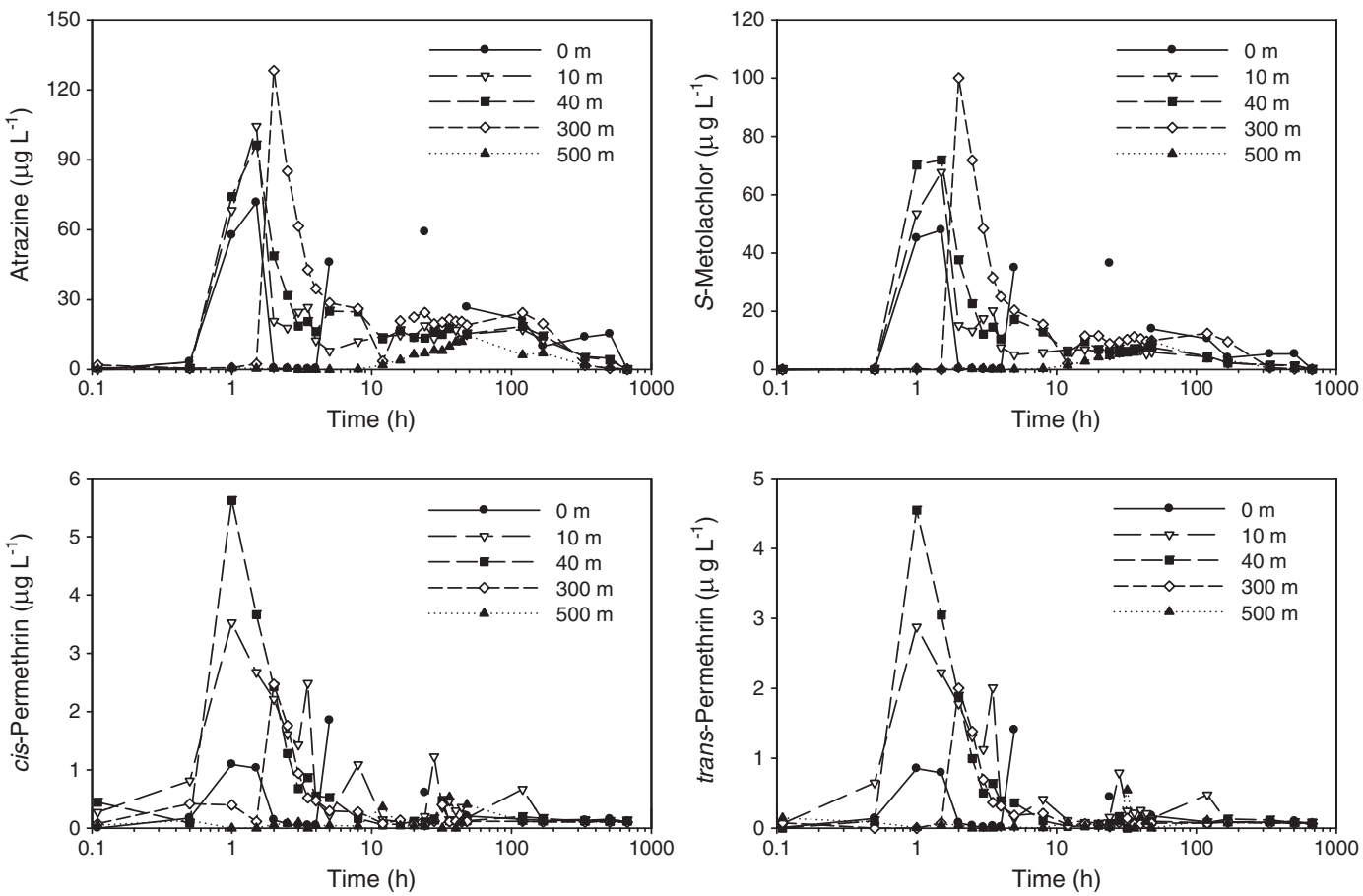

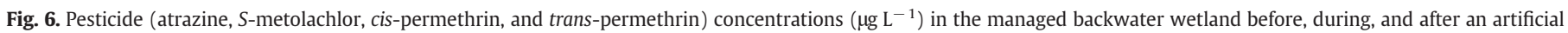
runoff event. 
Table 2

Sediment $\left(\mathrm{mg} \mathrm{L}^{-1}\right)$, nutrient $\left(\mathrm{mg} \mathrm{L}^{-1}\right)$ and pesticide $\left(\mu \mathrm{L}^{-1}\right)$ concentrations in the managed backwater wetland at $100 \mathrm{~m}$, when water was present.

\begin{tabular}{|c|c|c|c|c|c|c|c|c|c|}
\hline \multirow[t]{2}{*}{ Parameter } & \multicolumn{9}{|c|}{ Time $(\mathrm{h})$} \\
\hline & 1 & 1.5 & 2 & 2.5 & 3 & 3.5 & 4 & 5 & 672 \\
\hline TSS & 159 & 142 & 76 & 103 & 69 & 93 & 68 & 112 & 160 \\
\hline Total $\mathrm{PO}_{4}^{-}-\mathrm{P}$ & 2.77 & 4.00 & 3.94 & 2.86 & 2.22 & 2.13 & 1.46 & 1.33 & 1.05 \\
\hline Soluble $\mathrm{PO}_{4}^{-}-\mathrm{P}$ & 0.71 & 3.06 & 3.44 & 2.02 & 1.15 & 0.51 & 0.43 & 0.25 & 0.43 \\
\hline $\mathrm{NH}_{4}^{+}-\mathrm{N}$ & 0.12 & 0.40 & 0.42 & 0.27 & 0.16 & 0.08 & 0.08 & 0.06 & $\mathrm{U}^{\mathrm{a}}$ \\
\hline $\mathrm{NO}_{3}^{-}-\mathrm{N}$ & 0.06 & 0.06 & 0.05 & 0.05 & 0.04 & 0.04 & 0.03 & 0.05 & 0.07 \\
\hline $\mathrm{NO}_{2}^{-}-\mathrm{N}$ & 0.01 & 0.01 & 0.01 & 0.01 & 0.01 & 0.01 & 0.01 & 0.01 & 0.02 \\
\hline Total nitrogen & 4.18 & 6.75 & 7.14 & 5.58 & 2.98 & 2.52 & 2.36 & 2.81 & 4.07 \\
\hline Atrazine & 53.14 & 145.66 & 77.95 & 54.5 & 36.62 & 26.80 & 20.84 & 19.69 & $\mathrm{U}^{\mathrm{b}}$ \\
\hline$S$-metolachlor & 48.0 & 114.9 & 65.2 & 42.0 & 26.7 & 18.9 & 14.5 & 13.9 & $\mathrm{U}^{\mathrm{c}}$ \\
\hline cis-Permethrin & 2.6 & 7.2 & 3.1 & 1.7 & 1.0 & 0.8 & 0.6 & 0.4 & 0.1 \\
\hline trans-Permethrin & 2.1 & 4.5 & 2.5 & 1.3 & 0.7 & 0.6 & 0.4 & 0.3 & 0.1 \\
\hline
\end{tabular}

a Below detection limit of $0.02 \mathrm{mg} \mathrm{L}^{-1}$

b Below detection limit of $0.01 \mu \mathrm{g} \mathrm{L}-1$.

c Below detection limit of $0.1 \mu \mathrm{g} \mathrm{L}{ }^{-1}$.

ranged from $<0.02$ to $0.16 \mathrm{mg} \mathrm{L}^{-1}$ (Fig. 4); $\mathrm{NH}_{4}^{+}-\mathrm{N}$ was $<0.02 \mathrm{mg} \mathrm{L}^{-1}$ at each site (Fig. 5); $\mathrm{NO}_{3}^{-}-\mathrm{N}$ ranged from 0.03 to $0.05 \mathrm{mg} \mathrm{L}^{-1}$ (Fig. 5); $\mathrm{NO}_{2}^{-}-\mathrm{N}$ was $<0.02 \mathrm{mg} \mathrm{L}^{-1}$ at each site; and total $\mathrm{N}$ ranged from 2 to $6.7 \mathrm{mg} \mathrm{L}^{-1}$ (Fig. 5). All target pesticide concentrations were below detection in water samples collected prior to amendment at any sites. In addition, target pesticide concentrations observed in the source water from the lake cell used to simulate the rainfall event were below detection (Fig. 6).

During the runoff event $270.8 \mathrm{~kg}$ of soil was added to $611 \mathrm{~m}^{3}$ of water released from the lake cell, which should have generated an average TSS of $330 \mathrm{mg} \mathrm{L}^{-1}$, assuming $S_{\text {lake }}=7 \mathrm{mg} \mathrm{L}^{-1}$ and $w=30 \%$. Mean measured TSS at the release point during the runoff event was slightly higher, approximately $375 \mathrm{mg} \mathrm{L}^{-1}$. Peak TSS concentrations occurred within $3 \mathrm{~h}$ of amendment at $10 \mathrm{~m}, 40 \mathrm{~m}$, and $300 \mathrm{~m}$ downstream and showed 91-98\% decrease within $48 \mathrm{~h}$; samples at $500 \mathrm{~m}$ showed no changes (Fig. 4). Measured TSS concentrations at $100 \mathrm{~m}$ were never greater than $160 \mathrm{mg} \mathrm{L}^{-1}$ (Table 2). Forward stepwise regression analysis revealed that decreases in TSS were influenced by time but not distance from the point of amendment or total daily precipitation (Table 3 ). Due to significant fluctuations in TSS over time (Fig. 4), TSS aqueous dissipation half-lives could not be calculated. Wetland concentrations of total $\mathrm{PO}_{4}^{-}-\mathrm{P}$ and soluble $\mathrm{PO}_{4}^{-}-$ $\mathrm{P}$ peaked within $2.5 \mathrm{~h}$ of amendment at all sites, ranging from $5.54 \mathrm{mg} \mathrm{L}^{-1}$ at $0 \mathrm{~m}$ to $2.88 \mathrm{mg} \mathrm{L}^{-1}$ at $500 \mathrm{~m}$ for total $\mathrm{PO}_{4}^{-}-\mathrm{P}$ and $4.73 \mathrm{mg} \mathrm{L}^{-1}$ at $0 \mathrm{~m}$ to $0.29 \mathrm{mg} \mathrm{L}^{-1}$ at $500 \mathrm{~m}$ for soluble $\mathrm{PO}_{4}^{-}-\mathrm{P}$ (Table 2, Fig. 4). Aqueous total $\mathrm{PO}_{4}^{-}-\mathrm{P}$ decreased by $41-79 \%$ within $48 \mathrm{~h}$ and $60-85 \%$ by $672 \mathrm{~h}$ (day 28 ), whereas soluble $\mathrm{PO}_{4}^{-}-\mathrm{P}$ decreased by $96-98 \%$ within $48 \mathrm{~h}$. Soluble $\mathrm{PO}_{4}^{-}-\mathrm{P}$ attenuation length

Table 3

Standardized dimensionless regression coefficients and coefficients of determination for forward stepwise linear regressions computed using amended agrichemicals ( $\log _{10}$ transformed) as dependent variables and values of distance from inflow (Distance), sampling time (Time), and wetland volume at sampling time (Volume) as independent variables. Bold font indicates the largest standardized coefficient in each regression and blank cells indicate variables were dropped from stepwise regression due to a lack of significance.

\begin{tabular}{|c|c|c|c|c|c|c|}
\hline Dependent variable & $\mathrm{n}$ & Distance & Time & Volume & $\mathrm{R}^{2}$ & $p$-value \\
\hline TSS & 121 & & $-0.272^{\mathrm{a}}$ & & 0.074 & 0.0025 \\
\hline Total $\mathrm{PO}_{4}^{-}-\mathrm{P}$ & 122 & & $-0.452^{\mathrm{a}}$ & & 0.204 & $<0.0001$ \\
\hline Soluble $\mathrm{PO}_{4}^{-}-\mathrm{P}$ & 122 & & $-0.543^{a}$ & $0.234^{\mathrm{a}}$ & 0.199 & $<0.0001$ \\
\hline $\mathrm{NH}_{4}^{+}-\mathrm{N}$ & 122 & & $-0.455^{\mathrm{a}}$ & & 0.207 & $<0.0001$ \\
\hline $\mathrm{NO}_{3}^{-}-\mathrm{N}$ & 123 & 0.258 & 0.901 & -0.572 & 0.431 & $<0.0001$ \\
\hline $\mathrm{NO}_{2}^{-}-\mathrm{N}$ & 123 & 0.297 & 0.881 & -0.670 & 0.428 & $<0.0001$ \\
\hline Total nitrogen & 122 & & $-0.744^{a}$ & $0.256^{\mathrm{a}}$ & 0.315 & $<0.0001$ \\
\hline Atrazine & 122 & -0.354 & -0.413 & & 0.288 & $<0.0001$ \\
\hline S-metolachlor & 122 & -0.281 & -0.427 & & 0.256 & $<0.0001$ \\
\hline cis-Permethrin & 122 & & $-0.472^{\mathrm{a}}$ & & 0.222 & $<0.0001$ \\
\hline trans-Permethrin & 122 & & $-0.458^{a}$ & & 0.210 & $<0.0001$ \\
\hline
\end{tabular}

${ }^{a}$ Independent variable $\log _{10}$-transformed. in the initial pulse was $313 \mathrm{~m}$. Forward stepwise regression analysis revealed that total $\mathrm{PO}_{4}^{-}-\mathrm{P}$ decreases were influenced by time but not distance and soluble $\mathrm{PO}_{4}^{-}-\mathrm{P}$ decreases were influenced by time and wetland water volume but not distance (Table 3). Although total $\mathrm{PO}_{4}^{-}-\mathrm{P}$ aqueous dissipation half-lives could not be calculated for reasons similar to TSS, soluble $\mathrm{PO}_{4}^{-}-\mathrm{P}$ aqueous dissipation half-lives were determined and ranged from approximately $14 \mathrm{~min}$ at $10 \mathrm{~m}$ to $1 \mathrm{~h} 10 \mathrm{~min}$ at $300 \mathrm{~m}$ (Table 4).

Post-amendment wetland aqueous $\mathrm{N}$ concentrations varied depending upon $\mathrm{N}$ species. Peak $\mathrm{NH}_{4}^{+}-\mathrm{N}$ concentrations occurred within $2.5 \mathrm{~h}$ up to $300 \mathrm{~m}$ and $44 \mathrm{~h}$ at $500 \mathrm{~m}$, ranging from $0.56 \mathrm{mg} \mathrm{L}^{-1}$ at $0 \mathrm{~m}$ to $0.08 \mathrm{mg} \mathrm{L}^{-1}$ at $500 \mathrm{~m}$ (Table 2, Fig. 5) showing a decrease of $24-97 \%$ within $48 \mathrm{~h}$ and $92-100 \%$ by day $28 . \mathrm{NH}_{4}^{+}-\mathrm{N}$ attenuation length in the initial pulse was $417 \mathrm{~m}$. Forward stepwise regression showed that $\mathrm{NH}_{4}^{+}-\mathrm{N}$ decreases were influenced by time but not distance or wetland water volume (Table 3 ). $\mathrm{NH}_{4}^{+}-\mathrm{N}$ aqueous dissipation half-lives ranged from approximately $14 \mathrm{~min}$ at $10 \mathrm{~m}$ to $1 \mathrm{~h} 7 \mathrm{~min}$ at $100 \mathrm{~m}$ (Table 4). In contrast, $\mathrm{NO}_{3}^{-}-\mathrm{N}$ and $\mathrm{NO}_{2}^{-}-\mathrm{N}$ concentrations peaked at 21 to 28 days post-amendment ranging from 0.07 to $1.25 \mathrm{mg} \mathrm{NO}_{3}^{-}-\mathrm{N} \mathrm{L}^{-1}$ and $0.01-0.11 \mathrm{mg} \mathrm{NO}_{2}^{-}-\mathrm{N} \mathrm{L}^{-1}$ (Table 2, Fig. 5). Forward stepwise regression analysis revealed that $\mathrm{NO}_{3}^{-}-\mathrm{N}$ increases were influenced primarily by time and also by distance. $\mathrm{NO}_{2}^{-}-\mathrm{N}$ increases were influenced primarily by distance and also by time and wetland water volume (Table 3). Wetland TN concentrations followed a pattern more similar to $\mathrm{NH}_{4}^{+}-\mathrm{N}$. Peak TN occurred within $2.5 \mathrm{~h}$ ranging from $12.01 \mathrm{mg} \mathrm{L}^{-1}$ at $0 \mathrm{~m}$ to $4.00 \mathrm{mg} \mathrm{L}^{-1}$ at $500 \mathrm{~m}$ (Table 2, Fig. 5). Decreases of $31-81 \%$ within $48 \mathrm{~h}$ and $43-90 \%$ by day 28 were observed in aqueous TN. Forward stepwise regression analysis revealed that TN decreases were influenced primarily by time (Table 3 ). TN aqueous dissipation halflives ranged from approximately $10 \mathrm{~min}$ at $10 \mathrm{~m}$ to $1 \mathrm{~h} 42 \mathrm{~min}$ at $100 \mathrm{~m}$ (Table 4).

Patterns of post-amendment pesticide concentrations were similar to those of soluble $\mathrm{PO}_{4}^{-}-\mathrm{P}$ and $\mathrm{NH}_{4}^{+}-\mathrm{N}$ within the wetland. The more water soluble herbicides traveled farther downstream from the point of amendment and dissipated more slowly than the more hydrophobic insecticide, permethrin. Atrazine and S-metolachlor had attenuation lengths of $115 \mathrm{~m}$ and $149 \mathrm{~m}$, respectively, while less water soluble $S$-permethrin had the longest uptake length of $227 \mathrm{~m}$. Atrazine and $S$-metolachlor concentrations peaked within the first $2 \mathrm{~h}$ of amendment up to $300 \mathrm{~m}$ and $48 \mathrm{~h}$ at $500 \mathrm{~m}$. Peak herbicide concentrations ranged from $145.66 \mu \mathrm{g} \mathrm{L}^{-1}$ at $100 \mathrm{~m}$ to $14.79 \mu \mathrm{g} \mathrm{L}^{-1}$ at $500 \mathrm{~m}$ and $114.9 \mu \mathrm{g} \mathrm{L}^{-1}$ at $100 \mathrm{~m}$ to $9.8 \mu \mathrm{g} \mathrm{L}^{-1}$ at $500 \mathrm{~m}$ for atrazine and $S$-metolachlor, respectively (Table 2, Fig. 6). Aqueous atrazine concentrations decreased by $63-79 \%$ within $48 \mathrm{~h}$ and $99-100 \%$ by day 28 whereas $S$-metolachlor decreased by $71-91 \%$ within $48 \mathrm{~h}$ and approximately $100 \%$ at all sites by day 28 . Forward stepwise regression analysis revealed that aqueous atrazine and $S$ - 
Table 4

Aqueous exponential dissipation model results and calculated aqueous half-lives for nutrients in the managed backwater wetland (-, not calculated).

\begin{tabular}{|c|c|c|c|}
\hline Distance & Soluble $\mathrm{PO}_{4}^{-}-\mathrm{P}$ & $\mathrm{NH}_{4}^{+}-\mathrm{N}$ & Total nitrogen \\
\hline \multicolumn{4}{|l|}{$0 \mathrm{~m}$} \\
\hline Dissipation coefficient $(b)$ & 1.5841 & 1.8307 & 0.9271 \\
\hline Half-life $(\mathrm{h})\left(T_{1 / 2}\right)$ & 0.436 & 0.377 & 0.744 \\
\hline $\mathrm{R}^{2}$ & 0.901 & 0.798 & 0.701 \\
\hline F-value & 127.5 & 25.7 & 30.5 \\
\hline$p$-value & $<0.0001$ & $<0.0001$ & $<0.0001$ \\
\hline \multicolumn{4}{|l|}{$10 \mathrm{~m}$} \\
\hline Dissipation coefficient $(b)$ & 2.9734 & 2.9322 & 4.2877 \\
\hline Half-life $(\mathrm{h})\left(T_{1 / 2}\right)$ & 0.232 & 0.235 & 0.161 \\
\hline $\mathrm{R}^{2}$ & 0.882 & 0.878 & 0.773 \\
\hline F-value & 165.1 & 75.9 & 35.7 \\
\hline$p$-value & $<0.0001$ & $<0.0001$ & $<0.0001$ \\
\hline \multicolumn{4}{|l|}{$40 \mathrm{~m}$} \\
\hline Dissipation coefficient $(b)$ & 1.1178 & 1.3224 & 2.8450 \\
\hline Half-life $(\mathrm{h})\left(T_{1 / 2}\right)$ & 0.617 & 0.522 & 0.243 \\
\hline $\mathrm{R}^{2}$ & 0.974 & 0.930 & 0.904 \\
\hline$F$-value & 743.3 & 126.3 & 89.3 \\
\hline$p$-value & $<0.0001$ & $<0.0001$ & $<0.0001$ \\
\hline \multicolumn{4}{|l|}{$100 \mathrm{~m}^{\mathrm{a}}$} \\
\hline Dissipation coefficient $(b)$ & 0.6807 & 0.6146 & 0.4064 \\
\hline Half-life $(\mathrm{h})\left(T_{1 / 2}\right)$ & 1.014 & 1.123 & 1.698 \\
\hline $\mathrm{R}^{2}$ & 0.864 & 0.927 & 0.817 \\
\hline F-value & 38.2 & 76.1 & 22.4 \\
\hline$p$-value & 0.0008 & 0.0001 & 0.0052 \\
\hline \multicolumn{4}{|l|}{$300 m$} \\
\hline Dissipation coefficient $(b)$ & 0.5935 & 1.5167 & 0.9087 \\
\hline Half-life (h) $\left(T_{1 / 2}\right)$ & 1.163 & 0.455 & 0.759 \\
\hline $\mathrm{R}^{2}$ & 0.952 & 0.916 & 0.764 \\
\hline$F$-value & 393.1 & 97.9 & 30.7 \\
\hline$p$-value & $<0.0001$ & $<0.0001$ & $<0.0001$ \\
\hline \multicolumn{4}{|l|}{$500 \mathrm{~m}$} \\
\hline Dissipation coefficient $(b)$ & - & - & - \\
\hline Half-life $(\mathrm{h})\left(T_{1 / 2}\right)$ & - & - & - \\
\hline $\mathrm{R}^{2}$ & - & - & - \\
\hline F-value & - & - & - \\
\hline$p$-value & - & - & - \\
\hline
\end{tabular}

a When water was present.

metolachlor concentration decreases were influenced primarily by time and also by distance (Table 3). Aqueous dissipation half-lives of atrazine and S-metolachlor ranged from approximately 70-256 h and $35-186 \mathrm{~h}$, respectively, except at $100 \mathrm{~m}$ where aqueous half-lives were only $45 \mathrm{~min}$. Permethrin cis- and trans-isomers had peak concentrations within $2 \mathrm{~h}$ of amendment up to $300 \mathrm{~m}$ and $32-36 \mathrm{~h}$ at $500 \mathrm{~m}$. Peak permethrin isomer concentrations ranged from $7.2 \mu \mathrm{g} \mathrm{L} \mathrm{L}^{-1}$ at $100 \mathrm{~m}$ to $0.5 \mu \mathrm{g} \mathrm{L}-1$ at $500 \mathrm{~m}$ and $4.5 \mu \mathrm{g} \mathrm{L}-1$ at $40 \mathrm{~m}$ to $0.5 \mu \mathrm{g} \mathrm{L} \mathrm{L}^{-1}$ at $500 \mathrm{~m}$ for cis- and trans-permethrin, respectively (Table 2, Fig. 6). Aqueous cis-permethrin concentrations decreased by $81-98 \%$ within $48 \mathrm{~h}$ and $80-99 \%$ by day 28 whereas trans-permethrin decreased by $79-98 \%$ within $48 \mathrm{~h}$ and $89-99 \%$ by day 28 . Forward stepwise regression analysis revealed that cis- and trans-permethrin decreases were influenced by time but not distance or wetland water volume (Table 3). Aqueous cis- and trans-permethrin dissipation halflives ranged widely from approximately 30 min to $12 \mathrm{~h} 22 \mathrm{~min}$ and 36 min to 12 h 14 min, respectively (Table 5).

\section{Discussion}

The current study provides valuable information on the use and efficacy of natural wetlands modified to enhance their natural filtering capabilities when inundated with a complex mixture of sediment, nutrients, and pesticides typically occurring in agricultural runoff. As a result, such studies as the current one are important in
Table 5

Aqueous exponential dissipation model results and calculated aqueous half-lives for pesticides in the managed backwater wetland (-, not calculated).

\begin{tabular}{|c|c|c|c|c|}
\hline Distance & Atrazine & $\begin{array}{l}\text { S- } \\
\text { metolachlor }\end{array}$ & $\begin{array}{l}\text { cis- } \\
\text { Permethrin }\end{array}$ & $\begin{array}{l}\text { trans- } \\
\text { Permethrin }\end{array}$ \\
\hline \multicolumn{5}{|l|}{$0 \mathrm{~m}$} \\
\hline Dissipation coefficient $(b)$ & 0.0099 & 0.0196 & 0.0558 & 0.0564 \\
\hline Half-life $(\mathrm{h})\left(T_{1 / 2}\right)$ & 69.697 & 35.204 & 12.366 & 12.234 \\
\hline $\mathrm{R}^{2}$ & 0.713 & 0.834 & 0.963 & 0.974 \\
\hline$F$-value & 12.4 & 25.2 & 157.9 & 222.7 \\
\hline$p$-value & 0.0169 & 0.0041 & $<0.0001$ & $<0.0001$ \\
\hline \multicolumn{5}{|l|}{$10 \mathrm{~m}$} \\
\hline Dissipation coefficient $(b)$ & 0.0029 & 0.0046 & 0.2740 & 0.2911 \\
\hline Half-life $(\mathrm{h})\left(T_{1 / 2}\right)$ & 237.931 & 150.000 & 2.518 & 2.370 \\
\hline $\mathrm{R}^{2}$ & 0.860 & 0.907 & 0.794 & 0.847 \\
\hline$F$-value & 61.6 & 97.4 & 61.7 & 88.6 \\
\hline$p$-value & $<0.0001$ & $<0.0001$ & $<0.0001$ & $<0.0001$ \\
\hline \multicolumn{5}{|l|}{$40 \mathrm{~m}$} \\
\hline Dissipation coefficient $(b)$ & 0.0027 & 0.0053 & 0.8772 & 0.9110 \\
\hline Half-life $(\mathrm{h})\left(T_{1 / 2}\right)$ & 255.556 & 130.189 & 0.787 & 0.757 \\
\hline $\mathrm{R}^{2}$ & 0.820 & 0.935 & 0.980 & 0.989 \\
\hline$F$-value & 36.5 & 114.9 & 997.4 & 1749.8 \\
\hline$p$-value & 0.0003 & $<0.0001$ & $<0.0001$ & $<0.0001$ \\
\hline \multicolumn{5}{|l|}{$100 \mathrm{~m}^{\mathrm{a}}$} \\
\hline Dissipation coefficient $(b)$ & 0.8876 & 0.9313 & 1.4129 & 1.1352 \\
\hline Half-life $(\mathrm{h})\left(T_{1 / 2}\right)$ & 0.777 & 0.741 & 0.488 & 0.608 \\
\hline $\mathrm{R}^{2}$ & 0.973 & 0.985 & 0.985 & 0.995 \\
\hline$F$-value & 216.1 & 391.3 & 399.9 & 1131.8 \\
\hline$p$-value & $<0.0001$ & $<0.0001$ & $<0.0001$ & $<0.0001$ \\
\hline \multicolumn{5}{|l|}{$300 m$} \\
\hline Dissipation coefficient $(b)$ & 0.0036 & 0.0037 & 0.8843 & 0.9759 \\
\hline Half-life $(\mathrm{h})\left(T_{1 / 2}\right)$ & 191.667 & 186.486 & 0.780 & 0.707 \\
\hline $\mathrm{R}^{2}$ & 0.821 & 0.815 & 0.941 & 0.968 \\
\hline$F$-value & 46.0 & 44.2 & 317.4 & 614.0 \\
\hline$p$-value & $<0.0001$ & $<0.0001$ & $<0.0001$ & $<0.0001$ \\
\hline \multicolumn{5}{|l|}{$500 \mathrm{~m}$} \\
\hline Dissipation coefficient $(b)$ & 0.0077 & 0.0111 & - & - \\
\hline Half-life $(\mathrm{h})\left(T_{1 / 2}\right)$ & 89.610 & 62.162 & - & - \\
\hline $\mathrm{R}^{2}$ & 0.962 & 0.985 & - & - \\
\hline$F$-value & 100.4 & 269.0 & - & - \\
\hline$p$-value & 0.0006 & $<0.0001$ & - & - \\
\hline
\end{tabular}

a When water was present.

understanding the viability of using and managing available existing adjacent riverine floodplain wetlands within agricultural watersheds that can be modified to efficiently trap and remove agricultural contaminants as effectively as fully designed constructed wetlands but at much less cost and without the loss of any additional arable land. In the current study, attenuation efficiencies of TSS for the studied modified riverine floodplain wetland ranged from 91 to $98 \%$ within $48 \mathrm{~h}$ and were greater than that of another reported study assessing natural wetlands which ranged from $61 \%$ attenuation of TSS to $77 \%$ attenuation (Knox et al., 2008). By way of comparison, the ability of constructed wetlands to remove TSS can be constrained by the wetland design. For example, free surface water constructed wetlands with dense stands of macrophytes are highly efficient at removing TSS ranging from 82 to 88\% (Kröpfelová, 2008; Maynard et al., 2009) whereas sub-surface flow constructed wetlands with poor aeration are much less efficient ranging from approximately 28 to $35 \%$ (Noorvee et al., 2007; Wallace et al., 2008). Attenuation of TSS is an important factor since other agricultural contaminants are closely associated with TSS including nutrients such as total $\mathrm{PO}_{4}^{-}-\mathrm{P}$ and insecticides such as pyrethroids (Hladik and Kuivila, 2008). As a result, available riverine floodplain wetlands conducive to hydraulic modifications that increase hydraulic retention times can be a more cost-effective and efficient conservation practice than standard free water surface constructed wetlands (Shields et al., 2005; Kadlec, 2006) when used to mitigate agriculturally derived TSS. 
The use of a variety of wetland types to remove nutrients has been extensively studied. Fisher and Acreman (2004) conducted a thorough review on nutrient mitigation in natural wetlands and Vymazal (2007, 2011) provided an overview of nutrient attenuation among a wide variety of constructed wetland designs. For P, this study's modified riverine floodplain wetland was capable of removing total $\mathrm{PO}_{4}^{-}-\mathrm{P}$ by $41-79 \%$ within $48 \mathrm{~h}$ and $60-85 \%$ after 28 days while soluble $\mathrm{PO}_{4}^{-}-\mathrm{P}$ was rapidly removed from the water column by $96-98 \%$ within $48 \mathrm{~h}$. In comparison, Jordan et al. (2003) observed a restored natural flowthrough wetland to have $59 \%$ attenuation of total $\mathrm{P}$ from the water column but no net attenuation of other forms of $\mathrm{P}$ with average hydraulic retention times ranging from 12 to 19 days during the study period and minimum hydraulic retention times ranging from 0.51 to 2.2 days. Knox et al. (2008) observed a natural reference flow-through wetland having a short hydraulic retention time of $<2 \mathrm{~h}$ to have removed $35-42 \%$ of total $\mathrm{P}$ and soluble reactive $\mathrm{P}$ from the water column. Maynard et al. (2009), using two small surface flow-through constructed wetlands with hydraulic residence times ranging from 11 to $31 \mathrm{~h}$, measured $61-63 \%$ attenuation of dissolved reactive $\mathrm{P}$ and $55-65 \%$ attenuation of particulate P. This highlights the importance of hydraulic retention time in removing $\mathrm{P}$ from wetland water column with total $\mathrm{PO}_{4}^{-}-\mathrm{P}$ requiring greater retention times for attenuation than soluble $\mathrm{PO}_{4}^{-}-\mathrm{P}$.

Nitrogen attenuation from wetland water column is a complex process due to the many aqueous biogeochemical pathways through which $\mathrm{N}$ can be transferred from the water column (Vymazal, 2007; Reddy and DeLaune, 2008). Attenuation of dissolved inorganic nitrogen species such as $\mathrm{NH}_{4}^{+}-\mathrm{N}$ has been shown to vary greatly depending upon a variety of conditions found in natural wetlands (Garciá-Garciá et al., 2009; Hu et al., 2010), restored wetlands (Ardón et al., 2010), and designed constructed wetlands (Kohler et al., 2004; Noorvee et al., 2007; Vymazal, 2007; Kantawanichkul et al., 2008). In a study of natural Mediterranean stream-wetlands receiving agricultural runoff, $\mathrm{NH}_{4}^{+}-\mathrm{N}$ attenuation ranged from $11 \%$ attenuation to $213 \%$ export of $\mathrm{NH}_{4}^{+}-\mathrm{N}$ from these systems (Garciá-Garciá et al., 2009), while in another study using a restored wetland in an agricultural watershed, $\mathrm{NH}_{4}^{+}-\mathrm{N}$ attenuation ranged from $64 \%$ attenuation to $237 \%$ export of $\mathrm{NH}_{4}^{+}-\mathrm{N}$ from the system (Ardón et al., 2010). In comparison, the current study with a managed natural wetland showed $\mathrm{NH}_{4}^{+}-\mathrm{N}$ attenuation that ranged from 24 to $97 \%$ within $48 \mathrm{~h}$ and $92-100 \%$ by day 28 . This wetland had $\mathrm{NH}_{4}^{+}-\mathrm{N}$ and $\mathrm{PO}_{4}-\mathrm{P}$ attenuation lengths in the initial pulse that were less than the length of the wetland. This supports the idea that much of the readily bioavailable $\mathrm{N}$ and $\mathrm{P}$ are quickly attenuated from runoff pulses. Our estimates are also likely high in the context of nutrient attenuation for the entire wetland, as we only accounted for the fastest moving water during the release, and our estimates do not take into account areas of slower water exchange such as channel edges. Nitrate attenuation in natural and restored wetlands has been well established (Jordan et al., 2003; Fisher and Acreman, 2004; Fink and Mitsch, 2007; Woltemade and Woodward, 2008; Garciá-Garciá et al., 2009) although a few studies have observed $\mathrm{NO}_{3}^{-}-\mathrm{N}$ addition (Cooke, 1994; Knox et al., 2008). In the current study, no significant influx of $\mathrm{NO}_{3}^{-}-\mathrm{N}$ was measured during the dosing period, however, an addition of $\mathrm{NO}_{3}^{-}-\mathrm{N}$ and $\mathrm{NO}_{2}^{-}-\mathrm{N}$ that was time and site specific occurred on day 21 at only $300 \mathrm{~m}$ and $500 \mathrm{~m}$ downstream. By day 28, concentrations at both sites were similar to levels measured previously. These unusual results in conjunction with forward stepwise regression analysis (Table 3) imply influx of nitrate and nitrite into the wetland at or near $300 \mathrm{~m}$ and flowing downstream to $500 \mathrm{~m}$. This influx is possibly due to a localized runoff event from the adjacent agricultural field to the east of the wetland (Fig. 1) occurring on July 12-14, 2009 after sampling day 14 and before sampling day 21 when a total of $17.5 \mathrm{~mm}$ of precipitation fell (Fig. 3). Total $\mathrm{N}$ attenuation is often an important metric in wetlands because the parameter incorporates both inorganic and organic forms of $\mathrm{N}$ and is most clearly associated with eutrophication of aquatic systems. Attenuation of TN in natural wetlands receiving agricultural runoff range from 38 to $42 \%$ in wetlands with brief hydraulic retention times (0.5-2 h; Knox et al., 2008) and range from 51 to $88 \%$ in wetlands with longer hydrologic intermittency (Garciá-Garciá et al., 2009). Less effective at TN attenuation are restored wetlands which have $38-41 \%$ attenuation rates despite having retention times of days to weeks (Jordan et al., 2003; Fink and Mitsch, 2007). The managed wetland assessed in the current study had TN attenuation (43-98\%) comparable with those of natural wetlands having longer hydraulic retention time. It is noted, however, that TN attenuation in the current study was influenced by factors other than retention time including precipitation. In contrast, single-stage constructed wetlands provided only $40-50 \%$ TN attenuation, regardless of design type due, in part, to smaller treatment areas (Vymazal, 2007).

The ability of wetlands to effectively trap and remove pesticide mixtures in agricultural runoff has been the focus of numerous recent studies (Schulz and Peall, 2001; ; Sherrard et al., 2004; Budd et al., 2009; Moore et al., 2009; Locke et al., 2011; Maillard et al., 2011). As understanding of how complex pesticide mixtures from agricultural runoff may affect non-target aquatic biota increases (Schulz, 2004; Belden et al., 2007; Moore et al., 2007), questions remain about the most appropriate methods to trap and process complex pesticide mixtures from agricultural runoff before entering rivers, lakes or streams. As a result, research has focused primarily on use of constructed wetland systems that can be readily incorporated into agricultural watersheds as best management practices (Schulz and Peall, 2001; Budd et al., 2009; Moore et al., 2009; Locke et al., 2011) and has produced an USDA-NRCS standard (NRCS code 656; NRCS, 2010). In comparison, natural, pre-existing wetland systems occurring within an agricultural watershed landscape have shown promise in mitigating pesticide mixtures in agricultural runoff (Lizotte et al., 2009; current study) thus providing the same benefits as constructed wetlands without compromising crop production due to less available acreage. In the current study, the natural study wetland system with modification to enhance entrapment of agricultural contaminants proved efficient in attenuation of an atrazine-S-metolachlor-permethrin (both cis- and trans-permethrin isomers) mixture. The managed backwater wetland showed atrazine attenuation ranging from 63 to $85 \%$ within 48 h and 99 to $100 \%$ by day 28 and was comparable to attenuation reported by Locke et al. (2011) in a constructed wetland having attenuation of 70-89\% after 20 days. Atrazine attenuation observed in the current study was also similar to measured trapping efficiency of the same herbicide reported in a previous study at the inflow site of the same wetland by Lizotte et al. (2009) which showed decreases in aqueous atrazine concentrations of $65 \%$ by $48 \mathrm{~h}$ and $>90 \%$ by day 21 . With $S$-metolachlor, the current study showed attenuation of $71-91 \%$ within $48 \mathrm{~h}$ and $>99 \%$ attenuation by day 28 and was more efficient than the attenuation reported by Moore et al. (2001) in a constructed wetland having attenuation of $48-83 \%$ after 35 days. Comparisons of S-metolachlor attenuation in the current study with a previous study conducted in the same wetland by Lizotte et al. (2009) were also similar with decreases in aqueous $S$-metolachlor concentrations of $51 \%$ by $48 \mathrm{~h}$ and $>90 \%$ by day 15 at the inflow site. Insecticide permethrin attenuation efficiencies in our study ranged from $81-98 \%$ to $79-97 \%$ within $48 \mathrm{~h}$ for cis- and trans-permethrin isomers, respectively, and $80-99 \%$ within 28 days for cis- and trans-permethrin isomers, respectively. Our results were, again, comparable with the reported attenuation of $>90 \%$ of permethrin insecticide within a constructed wetland system (Budd et al., 2009) and much more efficient than the observed $4 \%$ attenuation of permethrin in a natural wetland receiving agricultural runoff (Lopéz-Flores et al., 2003).

\section{Conclusions}

Overall results of our study indicate that hydraulic management of a natural riverine backwater wetland can effectively trap a variety of contaminants commonly occurring in agricultural runoff during small to 
moderate rainfall events, mitigating potential ecological effects downstream within the main river channel. Controlled hydrology can be used to increase the efficiency of natural wetland filtering capabilities. The hydrologically modified riverine backwater wetland in the present study can rapidly (within $48 \mathrm{~h}$ ) trap and attenuate $90-98 \%$ of sediments, $40-80 \%$ of nutrients, and $80-98 \%$ of pesticides within $300 \mathrm{~m}$. Aqueous half-lives $\left(T_{1 / 2}\right)$ ranged from 20 to $30 \mathrm{~min}$ for soluble $\mathrm{PO}_{4}^{-}-\mathrm{P}, \mathrm{NH}_{4}^{+}-\mathrm{N}$, and TN, $0.7-2.4 \mathrm{~h}$ for permethrin and $1.5-10.6 \mathrm{~d}$ for atrazine and $S$ metolachlor. Attenuation efficiencies at the end of the 28 day study period were $\geq 85 \%$ for TSS, $\geq 60 \%$ for $P, \geq 43 \%$ for $N$, and $\geq 80 \%$ for pesticides within the entire $500 \mathrm{~m}$-long managed riverine wetland. Target agricultural contaminants were trapped from the water column relatively rapidly (days to weeks) within the wetland system. Modified and managed riverine backwater wetlands $\geq 1$ ha can efficiently trap agricultural runoff during moderate $(1 \mathrm{~cm})$ late-spring and earlysummer rainfall events, mitigating impacts to receiving rivers.

\section{Acknowledgments}

The authors thank the numerous technicians and support personnel who provided assistance with logistics, sample collection, and analysis. We also thank the several anonymous reviewers who provided helpful comments. Mention of equipment, computer programs, or a chemical does not constitute an endorsement for use by the US Department of Agriculture nor does it imply pesticide registration under FIFRA as amended. The US Department of Agriculture is an equal opportunity employer.

\section{References}

American Public Health Association (APHA). Standard methods for the examination of water and wastewater. 21st ed. ; 2005. American Public Health Association, American Water Works Association, and Water Environment Federation, Washington DC

Ardón M, Morse JL, Doyle MW, Bernhardt ES. The water quality consequences of restoring wetland hydrology to a large agricultural watershed in the southeastern coastal plain. Ecosystems 2010;13:1060-78.

Belden JB, Gilliom RJ, Lydy ML. How well can we predict the toxicity of pesticide mixtures to aquatic life? Integr Environ Assess Manag 2007;3:364-72.

Berenson ML, Levine DM, Goldstein M. Intermediate statistical methods and applications: a computer package approach. Englewood Cliffs, New Jersey: Prentice-Hall; 1983, 579 pp.

Budd R, O'Geen A, Goh KS, Bondarenko S, Gan J. Efficacy of constructed wetlands in pesticide removal from tailwaters in the Central Valley, California. Environ Sci Technol 2009;43:2925-30

Cooke JG. Nutrient transformation in a natural wetland receiving sewage effluent and the implications for waste treatment. Water Sci Technol 1994;29:209-17.

Fink DF, Mitsch WJ. Hydrology and biogeochemistry in a created river diversion oxbow wetland. Ecol Eng 2007;30:93-102.

Fisher J, Acreman MC. Wetland nutrient removal: a review of the evidence. Hydro Earth Syst Sci 2004;8:673-85

Garciá-Garciá V, Gómez R, Vidal-Abarca MR, Suárez ML. Nitrogen retention in natura Mediterranean wetland-streams affected by agricultural runoff. Hydrol Earth Syst Sci 2009;13:2359-71

Glantz SA. Primer of biostatistics. 4th ed. New York: New York; 1997. 473 pp.

Hladik ML, Kuivila KM. Occurrence of pyrethroids in bed and suspended sediments in California. In: Gan J, Spurlock F, Hendley P, Weston D, editors. Synthetic pyrethroids: occurrence and behavior in aquatic environments. America Chemical Society Symposium Series: 2008. p. 55-71. American Chemical Society, Washington DC

Hu L, Hu W, Deng J, Li Q, Gao F, Zhu J, et al. Nutrient removal in wetlands with different macrophyte structures in eastern Lake Taihu, China. Ecol Eng 2010;36:1725-32.

Jordan TE, Whigham DF, Hofmockel KH, Pittek MA. Nutrient and sediment removal by a restored wetland receiving agricultural runoff. J Environ Qual 2003;32:1534-47.

Kadlec RH. Free surface water wetlands for phosphorus removal: the position of the Everglades nutrient removal project. Ecol Eng 2006;27:361-79.

Kantawanichkul S, Pingkul K, Araki H. Nitrogen removal by a combined subsurface vertical down-flow and up-flow constructed wetland system. In: Vymazal J, editor Wastewater treatment, plant dynamics and management in constructed and natural wetlands. LaVergne, TN: Springer; 2008. p. 161-70.

Knox AK, Dahlgren RA, Tate KW, Atwill ER. Efficacy of natural wetlands to retain nutrient, sediment, and microbial pollutants. J Environ Qual 2008;37:1837-46.

Kohler EA, Poole VL, Reicher ZJ, Turco RF. Nutrient, metal, and pesticide removal during storm and nonstorm events by a constructed wetland on an urban golf course. Eco Eng 2004;23:285-98

Kröpfelová L. Constructed wetland Břehov: three years of monitoring. In: Vymazal J, editor. Wastewater treatment, plant dynamics and management in constructed and natural wetlands. LaVergne, TN: Springer; 2008. p. 181-90.
Lizotte RE, Shields FD, Knight SS, Bryant CT. Efficiency of a modified backwater wetland in trapping a pesticide mixture. Ecohydrology 2009;2:287-93.

Locke MA, Weaver MA, Zablotowicz RM, Steinriede RW, Bryson CT, Cullum RF. Constructed wetlands as a component of the agricultural landscape: mitigation of herbicides in simulated runoff from upland drainage areas. Chemosphere 2011;83:1532-8.

Lopéz-Flores R, Quintana XD, Salvadó V, Hidalgo M, Sala L, Moreno-Amich R. Comparison of nutrient and contaminant fluxes in two areas with different hydrological regimes (Empordà Wetland, NE Spain). Water Res 2003;37:3034-46.

Maillard E, Payraudeau S, Faivre E, Grégoire C, Gangloff S, Imfeld G. Removal of pesticide mixtures in a stormwater wetland collecting runoff from a vineyard catchment. Sci Total Environ 2011;409:2317-24.

Maynard JJ, O'Geen AT, Dahlgren RA. Bioavailability and fate of phosphorus in constructed wetlands receiving agricultural runoff in the San Joaquin Valley, California. J Environ Qual 2009;38:360-72.

McDowell LL, Willis GH, Murphree CE. Nitrogen and phosphorus yields in run-off from silty soils in the Mississippi Delta, U.S.A. Agric Ecosyst Environ 1989;25:119-37.

Mitsch WJ, Gosselink JG. Wetlands. 4th ed. Hoboken, New Jersey: John Wiley \& Sons; 2007. $582 \mathrm{pp}$.

Mitsch WJ, Lefeuvre J-C, Bouchard V. Ecological engineering applied to river and wetland restoration. Ecol Eng 2002;18:529-41.

Mitsch WJ, Day JW, Zhang L, Lane RR. Nitrate-nitrogen retention in wetlands in the Mississippi River Basin. Ecol Eng 2005;24:267-78.

Moore MT, Rodgers JH, Smith S, Cooper CM. Mitigation of metolachlor-associated agricultural runoff using constructed wetlands in Mississippi, USA. Agric Ecosyst Environ 2001;84:169-76.

Moore MT, Lizotte Jr RE, Knight S, Smith Jr S, Cooper CM. Assessment of pesticide contamination in three Mississippi Delta oxbow lakes using Hyalella azteca. Chemosphere 2007;67:2184-91.

Moore MT, Cooper CM, Smith S, Cullum RF, Knight SS, Locke MA, et al. Mitigation of two pyrethroid insecticides in a Mississippi Delta constructed wetland. Environ Pollut 2009;157:250-6.

Mostovoy GV, Anantharaj VG. Observed and simulated soil moisture variability over the lower Mississippi Delta region. J Hydrometeorol 2008·9:1125-50.

Noorvee A, Põldvere E, Mander U. The effect of pre-aeration on the purification processes in the long-term performance of a horizontal subsurface flow constructed wetland. Sci Total Environ 2007;380:229-36.

Reddy KR, DeLaune RD. Biogeochemistry of wetlands: science and applications. New York: CRC Press; 2008.

Scanlon BR, Jolly I, Sophocleous M, Zhang L. Global impacts of conversions from natural to agricultural ecosystems on water resources: quantity versus quality. Water Resour Res 2007;43(W03437):1-18

Schulz R. Field studies on exposure, effects, and risk mitigation of aquatic non-point source insecticide pollution: a review. J Environ Qual 2004;33:419-48.

Schulz R, Peall SKC. Effectiveness of a constructed wetland for retention of non-point source pesticide pollution in the Lourens River catchment, South Africa. Environ Sci Technol 2001;35:422-6.

Sherrard RM, Bearr JS, Murray-Gulde CL, Rodgers Jr JH, Shah YT. Feasibility of constructed wetlands for removing chlorothalonil and chlorpyrifos from aqueous mixtures. Environ Pollut 2004;127:385-94.

Shields Jr FD, Pearce CW. Control of agricultural nonpoint source pollution by natural wetland management. J Environ Sci Eng 2010;4:62-70.

Shields Jr FD, Knight SS, Stofleth JM. Alternatives for riverine backwater restoration by manipulation of severed meander bend. In: Walton R, editor. Proceedings of the 2005 World Water and Environmental Resources Congress: impacts of global climate change. American Society of Civil Engineers ProceedingsReston, VA: CDROM; 2005. http://dx.doi.org/10.1061/40792(173)566.

Smith Jr S. Pesticide retention by a programmable automatic water/suspendedsediment sampler. Bull Environ Contam Toxicol 1993;50:1-7.

Smith S, Cooper CM, Lizotte RE, Locke MA, Knight SS. Pesticides in lake water in the Beasley Lake watershed, 1998-2005. Int J Ecol Environ Sci 2007;33:61-71.

Statistical Package for the Social Sciences (SPSS). SigmaStat for Windows version 2.03; 1997.

Stream Solute Workshop. Concepts and methods for assessing solute dynamics in stream ecosystems. J North Am Benthol Soc 1990;9:95-119.

Tank JL, Rosi-Marshall EJ, Baker MA, Hall RO. Are rivers just big stream? A pulse method to quantify nitrogen demand in a large river. Ecology 2008;89:2935-45.

US Department of Agriculture, Natural Resources Conservation Service (NRCS). Conservation practice standard: constructed wetland (Ac.) Code 656; 2010. NRCS, NHCP.

Vymazal J. Removal of nutrients in various types of constructed wetlands. Sci Total Environ 2007;380:48-65.

Vymazal J. Constructed wetlands for wastewater treatment: five decades of experience. Environ Sci Technol 2011;45:61-9.

Wallace S, Nivala J, Meyers T. Statistical analysis of treatment performance in aerated and nonaerated subsurface flow constructed wetlands. In: Vymazal J, editor. Wastewater treatment, plant dynamics and management in constructed and natural wetlands. LaVergne, TN: Springer; 2008. p. 171-80

Wetzel RG. Clean water: a fading resource. Hydrobiologia 1992;243(244):21-30.

Willis GH, McDowell LL. Pesticides in agricultural runoff and their effects on downstream water quality. Environ Toxicol Chem 1982;1:267-79.

Woltemade CJ, Woodward J. Nitrate removal in a restored spring-fed wetland, Pennsylvania, USA. J Am Water Resour Assoc 2008;44:222-34. 